\title{
THE EFFECT OF MATHEMATICAL HABITS OF MIND LEARNING STRATEGY BASED ON PROBLEM TOWARD STUDENTS' MATHEMATICAL CREATIVE THINKING DISPOSITION
}

\author{
Sri Andriani ${ }^{1 \star}$, Kartika Yulianti ${ }^{2}$, Pandri Ferdias ${ }^{3}$, Siti Fatonah ${ }^{4}$ \\ ${ }^{1}$ Master student., Universitas Pendidikan Indonesia, INDONESIA, andriani0303@student.upi.edu \\ ${ }^{2}$ Dr., Universitas Pendidikan Indonesia, INDONESIA, ykar tika@yahoo.com \\ ${ }^{3}$ Dr., UIN Raden Intan Lampung, INDONESIA, pferdias@gmail.com \\ ${ }^{4}$ Master student., UIN Raden Intan Lampung, INDONESIA, sifa916@gmail.com \\ ${ }^{*}$ Corresponding author
}

\begin{abstract}
One of the evaluation standards given by the National Council of Teachers of Mathematics (NCTM) is mathematical disposition. Disposition refers not simply to attitudes but to a tendency to think and to act in positive ways. Creative thinking disposition is the tendency to thinking and acting creatively in mathematics. The aims of this research is to determine the effect of mathematical habits of mind learning based on problems toward the students' mathematical creative thinking disposition. This research was conducted at one of SMPN (Junior High School) Padang Ratu, Indonesia. The method used in this research is quasi experiment with posttest only control group research design. The population of this research is 214 students. The sample of this study is 70 students at grade VII which consists of 36 students in experimental group and 34 students in control group. The experimental group was taught by mathematical habists of mind learning strategy based on problem and the control group was taught by conventional learning strategy (teacher centered). The sampling technique used is cluster random sampling. The instrument used to collect data in this research is questionaire checklist to determine students' mathematical creative thinking disposition. Data analysis used in this research is t-test. The results showed that students' mathematical creative thinking disposition which is taught by mathematical habits of mind learning strategy based on problem are better than the students which taught by conventional learning strategy. In future research, we recommend to use the mathematical habits of mind learning strategy based on problem in learning process to increase student's creative thinking disposition.
\end{abstract}

Keyword: Mathematical habits of mind learning strategy base on problem, mathematical creative thinking disposition

\section{INTRODUCTION}

Mathematics is one of the subjects studied from elementary school through university, even into subjects compulsory tested nationally. According to Permen (Regulation of the Minister) No. 22 of 2006, the subjects of Mathematics should be given to all learners from primary schools to equip learners with the ability to think logically, analytically, systematically, critically, and creatively, as well as the ability to cooperate. The competencies required so that learners can have the ability to acquire, manage, and use information in order 
to survive in a state that is always changing, uncertain and competitive.

One of the important skill that can increase student's learning success is mathematic disposition, especially mathematical creative thinking disposition. It showed by one of the evaluation standards given by the National Council of Teachers of Mathematics (NCTM, 1989) is mathematical disposition Mathematical creative thinking disposition is important because it can make a person survive to face the problem, take responsibility, and accustom to do well in mathematics. Based on the explanation above, it is highly recommended for teachers to develop students' mathematical creative thinking disposition to students from elementary school.

Cuoco (2010) explain that Mathematical habits of mind can motivate the students to make connection between mathematics ideas. Fatonah (2015) by using mathematical habits of mind learning strategy based on problem reported that students obtained better grades on mathematical creative thinking ability than students' grades of conventional classes. Cuoco (2008) has advocated making mathematical habits of mind a key component of the syllabus because "without explicit attention to mathematical ways of thinking, the goals of intellectual sophistication" and "higher order thinking skills" will remain elusive." The number of studies show us that mathematical habits of mind learning strategy based on problems is one of the alternatif learning strategy that can improve student's mathematical creative thinking disposition.

Based on the explanation above, the researcher interested to investigate about "the effect of mathematical habits of mind learning strategy based on problem toward students' mathematical creative thinking disposition". The aims of this research is to determine the effect of mathematical habits of mind learning based on problems toward the students' mathematical creative thinking disposition. Research question in this study: is students' mathematical creative thinking disposition which is taught by mathematical habits of mind learning strategy based on problem are better than the students which is taught by conventional learning strategy?

\section{LITERATURE REVIEW}

\subsection{Mathematical Creative Thinking Disposition}

Da Ros and Voseles (2007) explain that "dispositions are frequent and voluntary habits of thinking and doing". The philosopher of education Robert Ennis (1987), defines a thinking disposition as a tendency to do something given certain conditions. Ennis argues, the disposition must be exercised reflectively. In other words, given the appropriate conditions, dispositions are not automatic.

Thinking dispositions are ongoing tendencies that guide intellectual behavior. They can be good or bad, productive or counter-productive (Perkins, Jay and Tishman, 1992). A thinking disposition, then, is a tendency, propensity, or inclination to think in certain ways under certain circumstances (Siegle, 1999).

Good thinking dispositions, the ones that normally describe productive intellectual behavior can be characterized as consisting of seven broad but key intellectual tendencies (Perkins, Jay \& Tishman, 1992). The following list describes these seven dispositions. Ideally, good thinking includes all of these dispositions exhibited appropriately at different times depending on the thinking situation. While other dispositions may contribute to good thinking, there are seven to be central efforts to teach thinking ought to cultivate them: 1) The disposition to be broad and adventurous. The tendency to be open-minded, to explore alternative views; an alertness to narrow thinking; the ability to generate multiple options; 2) The disposition toward sustained intellectual curiosity. The tendency to wonder, probe, find problems, a zest for inquiry; an alertness for anomalies; the ability to observe closely and formulate questions; 3) The disposition to clarify and seek understanding. A desire to understand clearly, to seek connections and explanations; an alertness to unclarity and need for focus; an ability to build conceptualizations; 4) The disposition to be planful and strategic. The drive to set goals, to make and execute plans, to envision outcomes; alertness to lack of direction; the ability to formulate goals and plans; 5) The disposition to be intellectually careful. The urge for precision, organization, thoroughness; an alertness to possible error or inaccuracy; the ability to process information precisely; 6) The disposition to seek and evaluate reasons. The tendency to question the given, to demand justification; an alertness to the need for evidence; the ability to weigh and assess reasons; 7) The disposition be metacognitive. The tendency to be aware of and monitor the flow of one's own thinking; alertness to complex thinking situations; the ability to exercise control of mental processes and to be reflective.

Base on the opinion about the thinking disposition according to experts, we can conclude that thinking disposition is the person's tendency in a positive acting in effort to indentifies the characteristic of thinking habits.

According to NCTM (1989) mathematical disposition is defined as attractiveness and appreciation toward 
mathematics. More broadly, mathematical disposition is not only as an attitude but also as a tendency for thinking and acting positively. Mathematical disposition has some aspects, that is: confidence, flexibility, willingness to persevere, interest, inclination to monitor and reflect, valuing the application of mathematics, and appreciation of the role of mathematics (NCTM, 1989). Disposition can be assessed by using observation on students' activity during discussion, solving problem, doing their individual tasks, and presenting students' work in small group discussion, or by using disposition scale (NCTM, 1989).

Polking (1998), proposed that mathematical disposition enclosed some traits and or habits namely: a) selfconcept in using mathematics, solving problem, reasoning, and communicating; b) flexible in seeking mathematical ideas and trying alternative solution of problem; c) diligent, interest, and curious in doing mathematics; d) tend to monitor, to reflect their own performance and reasoning; e) to evaluate application of mathematics into other mathematics situation, and daily life; f) to appreciate the roles of mathematics culture and value, and mathematics as tool and language.

Guilford (1967), explained that creativity is defined as the ability to produce valuable solutions to problems in an innovative way. According to Torrance (1989), the creative process is stimulated by sensitivity to problems, missing elements and discordance. It includes research and experiment of hypotheses regarding the nature of identified problems.

The definition about mathematical creative thinking disposition was explained by Maulana (Fatonah, 2015) mathematical creative thinking disposition is the tendency to think and act creatively in mathematics. Similar to Maulana's argument, Herlina (Fatonah, 2015) explain that mathematical creative thinking disposition is the the tendency to think and act creatively. These arguments above show that mathematical creative thinking disposition is the tendency toward positive attitude in mathematics. Base on the definitions, researchers conclude that mathematical creative thinking disposition is the tendency to think, to act, to do positive attitude creatively in mathematics.

According to Evans (1991), they are the aspects of creativity: awareness and sensitivity to problems, memory, fluency, flexibility, originality, selfdiscipline and persistence, adaptability, intellectual playfulness, humor, nonconformity, tolerance for ambiguity, self confidence, skepticism, and intelligence. According to Soemarmo (2014), the indicators of mathematical creative thinking disposition include: 1) open minded, tolerant to difference of idea; 2) flexible in thinking; 3) free to show the argument; 4) appreciate to fantasi and inisiative; 5) have the argument and hold it; 6) confident; 7) curiousity; 8) interest to abstracs and complex; 9) brave to take the risk, have comitmment to the task; 10) diligence; 11) sensitive to the surrondings; 12) concern to the present and to the future. In this research we used the indicators of mathematical creative thinking disposition that explained by evans, because the indicators by ivan can used to measure the student's mathematical creative thinking disposition.

\subsection{Mathematical Habits of Mind Learning Strategy Based on Problems}

Mathematical habits of mind (MHoM) definied as the web of specialized ways of approaching mathematical problems and thinking about mathematical concepts that resemble the ways employed by mathematicians (Cuoco, Goldenberg, \& Mark, 1997). These habits are not about particular definitions, theorems, or algorithms that one might find in a textbook; instead, they are about the thinking, mental habits, and research techniques that mathematicians employ to develop such definitions, theorems, or algorithms. A "Habit of Mind" means having a disposition toward behaving intelligently when confronted with problems, the answers to which are not immediately known (Costa, 2000).

According to Costa (2000), there are 16 characteristics of habits of mind, here they are: 1) Persisting, persisting is the condition when people don't give up easily. They are able to analyze a problem, to develop a system, structure, or strategy to attack a problem; 2) Managing impulsivity, managing impulsivity is the condition when people think before they act. They intentionally form a vision of a product, plan of action, goal or a destination before they begin; 3) Listening to others with understanding and empathy, some psychologists believe that the ability to listen to another person, to empathize with, and to understand their point of view is one of the highest forms of intelligent behavior; 4) Thinking flexibly, flexible people are the ones with the most control. They have the capacity to change their mind as they receive additional data; 5 ) Thinking about our thinking (metacognition), metacognition is our ability to know what we know and what we don't know. It is our ability to plan a strategy for producing what information is needed, to be conscious of our own steps and strategies during the act of problem solving, and to reflect on and evaluate the productiveness of our own thinking; 6) Striving for accuracy and precision, people who value accuracy, precision and craftsmanship take time to check over their products; 7) Questioning and posing problems, effective problem solvers know how to ask questions to fill in the gaps between what they know and what they don't know; 8) Applying past knowledge to new situations, intelligent human beings learn from 
experience. They are able to abstract meaning from one experience, carry it forth, and apply it in a new and novel situation; 9)Thinking and communicating with clarity and precision, Intelligent people strive to communicate accurately in both written and oral form taking care to use precise language, defining terms, using correct names and universal labels and analogies; 10) Gathering data through all senses, intelligent people know that all information gets into the brain through the sensory pathways: gustatory, olfactory, tactile, kinesthetic, auditory, visual. Most linguistic, cultural, and physical learning is derived from the environment by observing or taking in through the senses; 11) Creating, imagining, and innovating, creative human beings try to conceive problem solutions differently, examining alternative possibilities from many angles; 12) Responding with wonderment and awe, they are creative thinkers who have a passion for what they do; 13) Taking responsible risks, they accept confusion, uncertainty, and the higher risks of failure as part of the normal process and they learn to view setbacks as interesting, challenging and growth producing; 14) Finding humor, people who engage in the mystery of humor have the ability to perceive situations from an original and often interesting vantage point; 15) Thinking interdependently, human beings are social beings. Cooperative humans realize that all of us together are more powerful, intellectually and/or physically, than any one individual; 16) Learning continuously, intelligent people are in a continuous learning mode. Their confidence, in combination with their inquisitiveness, allows them to constantly search for new and better ways.

According to Barrow (Fatonah, 2015), problem base learning is the learning that face students to the problems. Base on the arguments above, researcher concluded that mathematical habits of mind based on problems is the mathematical habits of mind that integrated to problems base learning.

Steps of mathematical habits of mind learning strategy based on problem are: 1) explore the ideas; 2) formulate the questions; 3) construct examples; 4) identify problem solving approaches that are usefull in large class; 5) ask themselves whether there is "something more" (a generalization) in the content on which they are working; and 6) reflect on their answer to see whether they have made and error (Jacobbe and Millman, 2009).

Steps of problem based learning are: 1) presented the problems; 2) students disscused the problems in small group; 3) students solved the problems; 4) each of the students shared the information in peer teaching; 5) Students presented the solution of the problems; 6) Students reviewed what they learned (Huda, 2013).

Based on the steps of mathematical habits of mind learning strategy based on problem that explained by Jacobbe and Millman (2009) and steps of problem based learning that explained by Huda (2013), this research applied steps of mathematical habits of mind learning strategy based on problem that integrated with problem based learning. Researcher applied mathematical habits of mind learning strategy in every learning process to improve students' habits to thinking creatively.

\section{RESEARCH METHODOLOGY}

This research used quasi-experimental research methods. This method has the control group, but not able to function fully to control external variables that affect the implementation of the experiment. Quasiexperimental research is research which is closer to real trial where it is impossible to hold control or manipulate all relevant variables. There must be a compromise in determining the appropriate internal and external validity of existing boundaries. This research use only posttest research design.

The population in this study was students of class VII in one of SMP Negeri Padang Ratu Kabupaten Lampung Tengah. Class distribution of the population showed at the Table 1. Sampling technique in this research used cluster random sampling. The sample in this research was 70 students. The sample consists of two classes; there were class VIIE which consist of 36 students as the experiment group students and class VIID which consist of 34 students as the control group students. Data collecting technique used in this research was questionnaire checklist. The questionnaire checklist instrument to get the informations of mathematical creative thinking disposition in this research used likert scale. 
Table 1

\section{Students Distribution at VII grade SMP Negeri 1 Padang Ratu Lampung Tengah, Indonesia}

\begin{tabular}{ccc}
\hline No. & Class & Total of Students \\
\hline 1 & VII A & 35 \\
2 & VII B & 36 \\
3 & VII C & 36 \\
4 & VII D & 34 \\
5 & VII E & 36 \\
6 & VII F & 37 \\
\hline & Total & $\mathbf{2 1 4}$ \\
\hline
\end{tabular}

Sourch: Documentation of SMP (Junior High School) Negeri Padang Ratu, Indonesia

The indicators of mathematical creative thinking disposition in this researced explained by Evan (1991), they are the aspects of creativity: awareness and sensitivity to problems, memory, fluency, flexibility, originality, selfdiscipline and persistence, adaptability, intellectual playfulness, humor, nonconformity, tolerance for ambiguity, self confidence, skepticism, and intelligence. The questionaire consists of 20 statement, some of the statement in questionaire checklist can be seen at table 2 .

Table 2

Some Statements of mathematically creative thinking disposition

\begin{tabular}{|c|l|l|l|l|l|}
\hline \multirow{2}{*}{ No } & \multicolumn{1}{|c|}{ Indicators } & \multicolumn{1}{|c|}{ Statement } & \multicolumn{3}{|c|}{ Response } \\
\cline { 3 - 6 } & \multicolumn{1}{|c|}{ self confidence } & $\begin{array}{l}\text { Learning mathematics helps me to have } \\
\text { self-confident }\end{array}$ & A DA & SDA \\
\hline 2 & flexibility & $\begin{array}{l}\text { I like learning mathematics from various } \\
\text { books }\end{array}$ & & & \\
\hline 3 & $\begin{array}{l}\text { awareness and sensitivity } \\
\text { to problems }\end{array}$ & $\begin{array}{l}\text { I believe I can solve all kinds of mathematics } \\
\text { tasks }\end{array}$ & & & \\
\hline 4 & flexibility & $\begin{array}{l}\text { Learning math encourages me to think } \\
\text { freely }\end{array}$ & & & \\
\hline 6 & intelligence & $\begin{array}{l}\text { I believe I can solve any mathematical } \\
\text { difficulty }\end{array}$ & & & \\
\hline
\end{tabular}

SA: strongly agree; A: agree; DA: disagree; SDA : strongly disagree 


\section{RESULT AND DISCUSSION}

This research was conducted for eight meetings. Seven meetings were for treatment used mathematical habits of mind learning strategy base on problem in experiment group and conventional learning strategy in control group. One meeting was for post-test (questionaire of mathematical creative thinking disposition). Score of mathematical creative thinking disposition can be seen at the table 3 .

\section{Table 3}

\section{Score of mathematical creative thinking disposition}

Experiment Class and Control Class

\begin{tabular}{|c|c|c|c|c|c|c|}
\hline \multirow{2}{*}{ Class } & \multirow{2}{*}{$\begin{array}{l}\text { Ideal } \\
\text { Score }\end{array}$} & \multirow{2}{*}{$X_{\text {maks }}$} & \multirow{2}{*}{$X_{\min }$} & \multicolumn{3}{|c|}{ Tendency Central } \\
\hline & & & & $\overline{\mathbf{X}}$ & $\mathbf{M}_{\mathbf{e}}$ & $M_{0}$ \\
\hline Eksperiment & 100 & 96,25 & 53,75 & 80,694 & 83,75 & 83,75 \\
\hline Control & 100 & 91,25 & 55,00 & 74,779 & 77,50 & 77,50 \\
\hline
\end{tabular}

After researcher got the score of mathematical creative thinking disposition, then the researcher investigated the normalitas test and homogenitas test as the prerequisite test to choose which the statistics test will be used. Normalitas test in this research used Liliefors method. The result of normalitas test of mathematical creative thinking disposition at experiment class and contol class can be seen at the table 4 .

Table 4

The Result of Normalitas Test of

mathematical creative thinking disposition

\begin{tabular}{ccccl}
\hline No. & Class & $\mathrm{L}_{\text {count }}$ & $\mathrm{L}_{\text {table }}$ & Conclusions \\
\hline 1 & Eksperiment & 0,116 & 0,148 & Accepted $\mathrm{H}_{0}$ \\
2 & Control & 0,121 & 0,152 & Accepted $\mathrm{H}_{0}$ \\
\hline
\end{tabular}

Based on the result of normalitas test of mathematical creative thinking disposition at experiment class and contol class we can see that $\mathrm{L}_{\text {count }} \leq \mathrm{L}_{\text {table }}$, so we can conclude that $\mathrm{H}_{0}$ accepted, it mean that the sample has normal distribution.

Homogentitas test in this research used Bartlett method. The result of homogenitas test of mathematical creative thinking disposition at experiment class and contol class can be seen at the table 5.

Table 5

The Result of Homogenitas Test

of mathematical creative thinking disposition

\begin{tabular}{cccc}
\hline Class & $\mathbf{X}_{\text {count }}^{2}$ & $\mathbf{X}_{\text {table }}$ & Conclusion \\
\hline Experiment and control & 1,032 & 3,481 & Accepted $\mathrm{H}_{0}$ \\
\hline
\end{tabular}


Based on the computation, it can be seen that $X_{\text {count }}^{2} \leq X_{\text {table }}^{2}$, so we can conclude that $H_{0}$ accepted, it mean that the sample was homogen.

The data was normal and homogen, so that the researcher used statistical parametric test (t-test). T-test was used to investigate the effect of independent variable (mathematical habits of mind learning strategy base on problem) toward dependent variables (mathematical creative thinking disposition). The result of $t$-test can be seen at the table 6.

Tabel 6

The Result of t-test

of mathematical creative thinking disposition

\begin{tabular}{cccl}
\hline Class & $\mathbf{T}_{\text {count }}$ & $\mathbf{t}_{\text {table }}$ & Conclusion \\
\hline Experiment and control & 2,266 & 1,995 & Rejected $\mathrm{H}_{0}$ \\
\hline
\end{tabular}

Based on table 5 , the result of $t$-test were $t_{\text {count }}=2,266$ and $t_{\text {table }}=1,995$. Based on that result, it can be seen that $t_{\text {count }}>t_{\text {table }}$, so we can conclude that $H_{0}$ rejected. It means that the mathematical creative thinking disposition of students who obtain mathematical habits of mind learning strategy based on problem is better than the mathematical creative thinking disposition of students who obtaining conventional learning strategy.

Here the factors that can make mathematical habits of mind learning strategy based on problem is better than the mathematical creative thinking disposition of students who obtaining conventional learning strategy:

a. The learning process with mathematical habits of mind learning strategy based on problem, the teacher designed the student in group, so that students can share their experience about learning mathematics.

b. The learning process with mathematical habits of mind learning strategy based on problem motivate the student evaluate and conclude what they've learned, so that student aware about what they understand and what they don't understand.

\section{CONCLUSIONS}

Based on the analysis and discussion of the results that have been described previously, we can conclude that the mathematical creative thinking disposition of students who obtain mathematical habits of mind learning strategy based on problem is better than the mathematical creative thinking disposition of students who obtaining conventional learning strategy.

The suggestion of that conclusion is as follows. Problem base teaching strategy such as mathematical habits of mind learning strategy base on problem has a big opportunity for improving students' mathematical creative thinking disposition and may be for other high level mathematical thinking. Thus, to improve students' mathematical creative thinking disposition, teacher should be creative to select and to adopt innovative teaching such as mathematical habits of mind learning strategy base on problem.

\section{ACKNOWLEDGMENT}

The study has been suported by Indonesia Endowment Fund of Education (LPDP), so we would like to say thank you to LPDP. We thank to the mathematics teacher and the principal for allow me to conduct this research. We thank to Mr. Al Jupri, Ph.D and Siti Fatimah, Ph.D as the reviewer of this article.

\section{REFERENCE LIST}

Costa, A. \& Kallick, B. (2000). Habits of Mind: A Developmental Series. Alexandria, VA: Association for Supervision and Curriculum Development

Costa, A. \& Kallick, B. (2008). Describing 16 Habits of Mind. [Online]. Available at: http://www.habits-of- 
mind.net/pdf/16HOM2.pdf.

Cuoco, A.L.J., et al. (2010). Habits of Mind. An Organizing Principle For Mathematcs Curricula. Journal of Mathematical Behavior 15, 375-402.

Cuoco, A. (2008). Mathematical habits of mind: An organizing principle for curriculum design. Proceedings of the 31st annual meeting of the North American Chapter of the International Group for the Psychology of Mathematics Education. Atlanta, GA: Georgia State University.

Cuoco, A., Goldenberg, E. P., \& Mark, J. (1997). Habits of mind: An organizing principle for mathematics curriculum. Journal of Mathematical Behavior, 15(4), 375-402.

Da Ros, D., \& Voseles. (2007). Why Children's Disposition Should Matter to All Teachers [On-line]. In https://www.naeyc.org/files/yc/file/200709/DaRos-Voseles.pdf

Depdiknas. (2002). Pendekatan Kontekstual. Jakarta :Dirjen Dikdasmen.

Ennis, R. H. (1987). A taxonomy of critical thinking dispositions and abilities. In J. B. Baron and R. S. Sternberg (Eds.), Teaching thinking skills: Theory and practice. New York: W. H. Freeman.

Fatonah, S. (2015). "Pengaruh Strategi Pembelajaran Mathematical Habits Of Mind (MHM) Berbasis Masalah Terhadap Kemampuan Berpikir Kreatif Matematis Dan Disposisi Berpikir Kreatif". Disertation at Post Graduate Studies at UIN Raden Intan, Lampung, Indonesia, unpublished.

Guilford, J. P. (1967). The nature of human intelligence. New York: McGraw-Hill

Huda, M. (2013). Model-Model Pengajaran dan Pembelajaran. Yogyakarta: Pustaka Pelajar.

Mahmudi, A., \& Sumarmo, U. (2009). "Pengaruh Strategi Pembelajaran Mathematical Habits of Mind (MHM) Berbasis Masalah terhadap Kreativitas Peserta didik". Jurnal Cakrawala Pendidikan, 1(3), 58-75

NCTM. (1989). Curiculum and Evaluation Standards for School Mathematics. USA: NCTM

Perkins, D., Jay, E., \& Tishman, S. (1992). Beyond abilities: A dispositional theory of thinking. The MerrillPlamer Quarterly.

Permendikbud (Regulation of Minister). (2006). Lampiran Peraturan Menteri Pendidikan dan Kebudayaan Nomor 21 Tahun 2006 tentang Standar Isi Pendidikan Dasar dan Pendidikan Menengah. Jakarta: BSNP

Siegel, H. (1999). What (Good) Are Thinking Dispositions?. International Journal Of Mathematical Education, 49 (2), 207-221

Soemarmo, U. (2014). Penilaian Pembelajaran Matematika. Bandung: Refika Aditama

Tim, J \& Millman, R. (2009). Mathematical Habits of The Mind for Presevice Teachers. School Science and Mathematics, 109 (5), 298-302

Torrance, E. P. (1989). Test di pensiero creativo, manuale tecnico e norme. Firenze: Organizzazioni Speciali. 